\title{
Mouth Preparation Pada Anak Dengan Kelainan Jantung Kongenital Tetralogi of Fallot, Pre-operatif Kardiovaskuler
}

\section{Muhammad Harun Achmad, Maryanne Susanti}

Peserta Pendidikan Dokter Gigi

Spesialis Bagian IImu Kedokteran Gigi Anak

Fakultas Kedokteran Gigi Universitas Padjajaran Bandung, Indonesia

\begin{abstract}
Teeth dimension is the factor influenced the incidence of tooth impaction. The most The congenital figure of the heart defect incident in several educational hospitals in Indonesia almost reached 9 per 1,000 born babies who survive to live (0.8-1.2\%). Tetralogi of Fallot was one of the cyanotic congenital heart defects that were often found to children. This situation had four forms of the deviation: defect of the ventricle septum, overriding aorta, stenosis infundibuler, and hypertrophy of the right ventricle. As in the case of other congenital heart defect, in Tetralogi Fallot often happened fatal complication such as endocarditis bacterialis that had tight relationship to the infection in teeth. In dentistry, the treatment for children with cardiovascular disease needs holistic handling to prevent the occurrence endocarditis bacterialis. This paper discussed the teeth and the mouth conditions as well as the therapy in two cases of the child with tetralogi of Fallot. Two female patients came to the Special Dental Care clinic, RSHS Bandung with the congenital Tetralogi of Fallot heart defect to undergo mouth preparation prior to the heart operation in Jakarta. The conclusion is as in the case of the congenital heart other defect cyanotic, in Tetralogi Fallot fatal complications such as endocarditis bacterialis could happen. Endocarditis bacterialis was caused by the ": bacterial infection in the heart valve or endocardium.
\end{abstract}

The key word: Tetralogi of Fallot, cardiovascular diseases, endocarditis bacterialis. 


\section{ABSTRAK}

Angka kejadian kelainan jantung kongenital di beberapa rumah sakit pendidikan di Indonesia mencapai 9setiap IOOObayi lahirhidup(0,81,2\%menurutWHO). Tetralogi of Fallot merupakan salah satu kelainan jantung kongenital sianotik yang paling banyak ditemukan pada anak. Keadaan ini memiliki empat bentuk kelainan yang terdiri dari defek septum ventrikel, overriding aorta, stenosis infundibuler, dan hipertrophy ventrikel dextra. Seperti halnya kelainan jantung kongenital lainnya, pada Tetralogi Fallot sering terjadi komplikasi yang fatal, antara lain endokarditis bakterialis yang berhubungan erat dengan infeksi pada gigi. Penatalaksanaan anak penderita penyakit kardiovaskuler di bidang kedokteran gigi memerlukan penanganan secara utuh, dalam upaya mencegah terjadinya endokarditis bakterialis. Makalah ini membahas keadaan gigi dan mulut serta penatalaksanaannya pada dua anak dengan Tetralogi Fallot. Dilaporkan dua pasien anak perempuan datang ke klinik Special Dental Care bagian Bedah Mulut RSHS Bandung dengan kelainan jantung kongenital Tetralogi Fallot untuk dilakukan mouth preparation sebelum dilakukan operasi jantung di Jakarta. Sebagai simpulan adalah seperti halnya kelainan jantung kongenital sianotik lainnya, pada Tetralogi Fallot dapat terjadi komplikasi yang fatal antara lain endokarditis bakterialis. Endokarditis bakterialis disebabkan oleh infeksi bakteri pada katup jantung atau endokardium. Di bidang kedokteran gigi, endokarditis bakterialis erat hubungannya dengan infeksi gigi.

Kata kunci: penyakit kardiovaskuler, endokarditis bakterialis.

Koresponden : Muhammad Harun Achmad, Peserta Pendidikan

Dokter Gigi Spesialis Bagian IImu Kedokteran Gigi Anak Fakultas Kedokteran Gigi Universitas Padjajaran Bandung, Indonesia.

\section{PENDAHULUAN}

Penanganan penyakit anak secara holistik dan komprehensif dewasa ini sangat penting, meliputi semua aspek penanganan pasien seperti aspek preventif, promotif, kuratif, rehabilitatif serta aspek psikososial, sesuai dengan prinsip 
penanganan pada pasien secara umum. Hal tersebut berlaku juga dengan pasien anak yang menderita penyakit kardiovaskular yang memerlukan penanganan secara utuh, termasuk penanganan berbagai aspek di luar masalah kardiovaskular, termasuk kelainan pada gigi dan ronggamulutnya. ${ }^{1,2}$

Kelainan jantung pada anak dibedakan atas 2 jenis, yaitu kelainan jantung bawaan dan kelainan jantung didapat. Secara garis besar kelainan jantung bawaan dibagi menjadi kelainan jantung bawaan sianotik dan kelainan jantung bawaan nonsianotik. Kelainan jantung bawaan sianosis secara klinis dapat disebabkan oleh berbagai faktor, seperti pneumonia, sepsis, hipoglikemia dan gangguan sirkulasi pada gagal jantung kongestif. ${ }^{12}$

Tindakan perawatan gigi dapat menimbulkan bakteriemia yang pada akhirnya dapat menimbulkan endokarditis infektif. Endokarditis infektif merupakan penyakit yang disebabkan oleh infeksi mikroba pada lapisan endotelium jantung dan pembuluh darah besar. Penyakit ini ditandai dengan terbentuknya vegetasi yang dapat terjadi pada katup jantung (baik katup buatan maupun natif), endokardium dan benda asing intravaskuler seperti benda penutup defek atau membuat pirau intrakardiak untuk memperbaiki kelainan jantung bawaan. Timbulnya bakteriemia dapat berasal dari perawatan yang dilakukan di ruang praktek dokter gigi atau sebagai akibat dari aktivitas sehari-hari seperti mengunyah, menyikat gigi atau flossing padamulutyangsehat. ${ }^{12}$

Berdasarkan latar belakang tersebut di atas, pada makalah ini akan disajikan studi kasus mengenai mouth preparation pada dua anak dengan kelainan jantung kongenital tetralogi offallot, pre-operatif kardiovaskuler.

\section{Tinjauan Pustaka}

$$
\text { Tetralogi Fallot }
$$

(ToF) merupakan kelainan jantung sianotik yang paling banyak ditemukan, yaitu sekitar $7-10 \%$ dari seluruh kelainan jantung kongenital pada anak. Kelainan ini terdiri dari defek septum ventrikel, overriding aorta, stenosis pulmonalis, dan hipertrofi ventrikel dekstra. $^{12}$ Gambaran empat kunci utama ToF adalah adanya lubang pada dinding di antara ventrikel (defek septum ventrikel) sehingga darah miskin oksigen tercampur dengan darah kaya oksigen. Adanya obstruksi dari ventrikel kanan hingga paru-paru \{stenosis pulmonalis) merupakan 
gambaran yang terpenting. Selain itu, aorta berjalan langsung (overriding) di atas defek septum ventrikel sehingga ototventrikel kanan menebal. $^{2}$

Sekitar 10\% kasus CHD adalah kasus ToF. Anak-anak yang menderita ToF yang belum dilakukan pembedahan jantung, memiliki variasi anatomi dan fisiologi yang luas, sehingga memerlukan pemeriksaan sebelum dilakukan pembedahan. Pada ToF, kejadian dari infundibular dan valvular pulmonic stenosis (PS) terjadi sekitar $75 \%$ dari seluruh kasus, sedang sisanya adalah isolated infundibular stenosis. Setelah ditentukan prosedur bedah jantung yang akan dilaksanakan, anatomi yang mengalami cacat, dan keparahan malformasi anatomi, cardiac grid untuk pasien tersebut dapat ditentukan. Adanya overriding aorta di atas defek ventrikel dan stenosis pulmonal menyebabkan darah dari ventrikel kiri dan kanan dipompa ke dalam tubuh. Adanya darah miskin oksigen dalam tubuh menyebabkan anak dengan ToF terlihat kebiruan. ${ }^{2,3}$

Seorang anak yang mengidap ToF mudah merasa Jelah, sesak dan hiperpneu, karena hipoksia. Sianosis kadang-kadang tidak terlihat jelas. Ujung-ujung jari tampak membentol dan berwarna biru yang disebut jari tabuh \{clubbing finger). Anak seeing melakukan squatting (jongkok) setelah berjalan jarak tertentu atau pada waktu setelah menangis. Posisi squatting ini diperlukan untuk membantu meningkatkan resistensi perifer dan menahan alir balik darah dari ekstremitas bawah ke jantung. Selain itu, peningkatan tahanan sistemik dengan jongkok juga akan memperbaiki oksigenasi paru. ${ }^{\mathrm{J}}$

Seperti halnya kelainan jantung kongenital sianotik lainnya, pada ToF kadang-kadang terjadi komplikasi yang fatal, antara lain endokarditis bakterialis. Insidensi endokarditis bakterialis pada ToF meliputi i5\%. Endokarditis bakterialis disebabkan oleh infeksi bakteri pada katup jantung atau endokardium. Di bidang kedokteran gigi, endokarditis bakterialis erat hubungannya dengan infeksi gigi. Gigi-gigi pada anak dengan ToF sering ditemukan dalam keadaan buruk akibat gangguan perkembangan email. Sering pula terjadi hipertrofi gingiva dan lidah menunjukkan gambaran seperti peta \{geographic tongue). Peran dokter gigi sangat diperlukan dalam upaya pencegahan komplikasi ini. ${ }^{2,4}$

Prosedur perawatan gigi invasif seperti ekstraksi, scaling, dan 
perawatan endodontik dapat menyebabkan bakteriemia. Setiap tindakan perawatan gigi yang dapat menyebabkan kerusakan pada jaringan lunak atau tulang yang mengarah pada perdarahan dapat menyebabkan transient bacteriemia.

Keadaan ini pada beberapa pasien tertentu dapat menimbulkan endokarditis. Perawatan gigi minor seperti pemasangan pita matriks dapat menyebabkan transient bakteriemia yang selanjutnya mengarah pada endokarditis bakterialis. Upaya untuk mencegah endokarditis bakterialis adalah dengan pemberian antibiotik profilaksis. Streptokokkus oral seperti S. sanguis dan S. mitis merupakan organisme yang paling sering menyebabkan endokarditis bakterialis. $^{4}$

Anak-anak dengan kelainan jantung kongenital seperti ToF berisiko tinggi terkena karies, terutama pada gigi sulung. Hal ini terjadi karena beberapa obat-obatan untuk penyakit jantung mengandung gula. Selain itu, terdapat pula peningkatan prevalensi gangguan mineralisasi enamel. Tindakan preventif yang meliputi konseling diet, pemberian fluor, pit dan fissure sealant \{uenutupan pit dan fisur yang dalam pada gigi molar sebagai lisaha mencegah terjadinya akumulasi food debris yang dapat berlanjut ke pembentukan karies), dan instruksi pemeliharaan kebersihan mulut perlu dilakukan. $^{1 \times 6}$

\section{LAPORAN KASUS}

\section{Kasus Pertama}

Asti, seorang anak perempuan berusia 13 tahun datang ke klinik Special Dental Care Rumah Sakit Hasan Sadikin Bandung atas rujukan dari Bagian Kardiolog Anak untuk mencari fokal infeksi dan penatalaksanaannya sebelum dilakukan operasi jantung di Rumah Sakit Harapan Kita Jakarta. Pasien didiagnosis dengan Tetralogi Fallot dan kardiomiopati hipertropi, dengan gejala-gejala klinis berupa mudah lelah, sesak, dan sering jongkok yang sudah tampak sejak usia balita. Saat ini pasien tidak kuat berjalan sehingga hams selalu digendong.

Diagnosis kerja akhir dari Bagian Kardiologi Anak adalah DF, yaitu compensated heart disease, DA, yaitu ToF, dan DE, yaitu CHD cyanotic type. Dari pemeriksaan fisik terlihat keterlambatan pertumbuhan dan perkembangan pasien. Pasien tampak lemah dan kebiruan. Tampak pada gambar 1, jari-jari tangan dan kaki membentol (clubbing). 
Pada pemeriksaan klinis ditemukan keadaan sebagai berikut, status umum berupa nadi 89 kali permenit, pernapasan 22 kali permenit, ekspresi muka tenang, suhu afebris. Sedangkan pada status lokalis terlihat ekstra oral tidak ada kelainan. Pada pemeriksaan intra oral terlihat ulkus pada sudut mukosa bibir kanan, dan gingiva sianotik. Terdapat diagnosis gangren pulpa pada gigi 11, 31, 41, 21, 26 , gangren radiks 55 , dan hiperemi pulpa 37, 42, 47, 16, 36, 32, 46. Kebersihan mulut kurang. Rencana perawatan yang akan dilakukan meliputi tindakan preventif dan kuratif. Preventif dilakukan dengan instruksi pemeliharaan kebersihan mulut, dan aplikasi fluor secara topikal. Sedangkan tindakan kuratif berupa ekstraksi gigigigi dengan diagnosis gangren pulpa dan penambalan gigi-gigi yang mengalami hiperemi pulpa

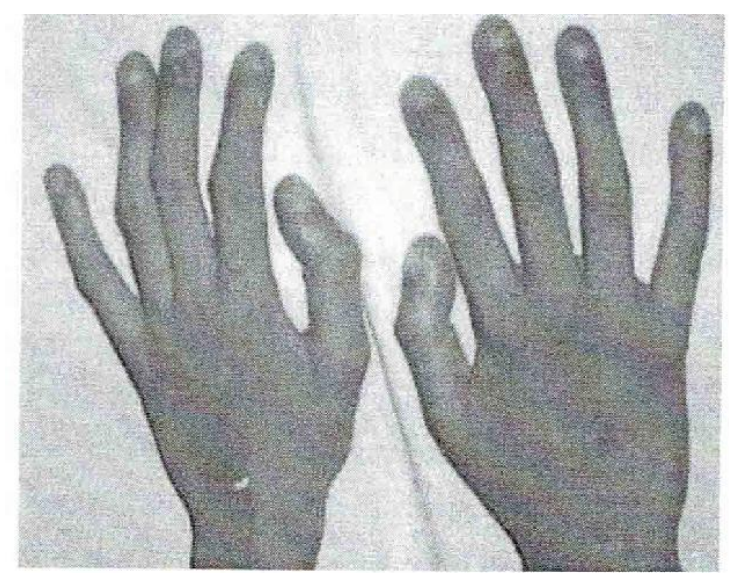

dengan menggunakan semen glass ionomer. Untuk mencegah endokarditis bakterialis, pasien diberi profilaksis antibiotik $50 \mathrm{mg} / \mathrm{kg}$ BB 1 jam sebelum tindakan. Selama tindakan perawatan gigi berlangsung pasien dimonitor saturasi oksigen, denyut jantung, dan diberi oksigen.

Pada kunjungan pertama dicoba untuk melakukan perawatan dengan pendekatan konvensional (behavior management), namun tidak berhasil karena pasien kurang kooperatif utamanya pada penanganan ekstraksi gigi dalam jumlah banyak pada gigi dengan gangren pulpa sehingga direncanakan untuk dilakukan perawatan dibawah anestesi umum. Sebelumnya, dilakukan pemeriksaan laboratorium, foto ronsen toraks dada, dan joint conference dengan Bagian Anestesi dan Kesehatan Anak.

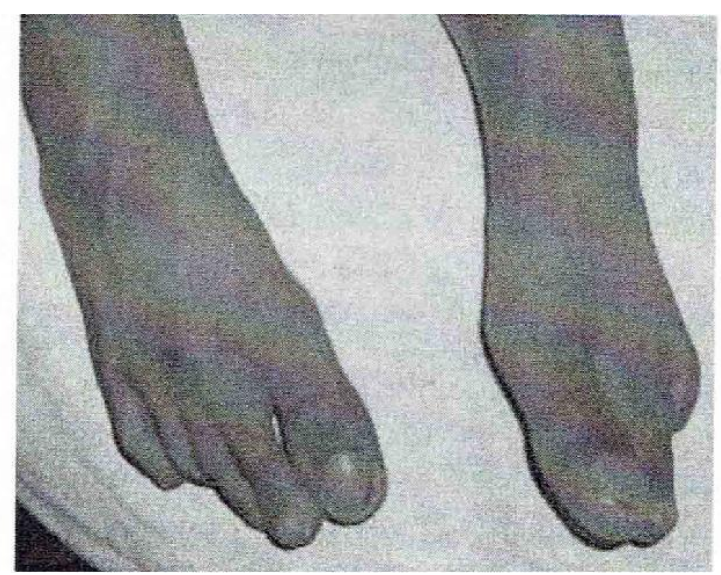

Gambar 1. Jari-jari tangan dan kaki pasien yang clubbing dan sianotik (pasien 1) 
Hasil foto ronsen toraks menunjukkan adanya pembesaran jantung of increase vascular marking, tidak tampak spesifik proses aktif, dan bayangan opak bulat paratracheal kanan. Dari hasil joint conference, perawatan gigi dibawah anestesi umum tidak dapat dilakukan di Bagian Bedah Mulut RSHS Bandung karena pasien termasuk Tetralogi Fallot berat sehingga berisiko tinggi dan keluarga pasien tidak mau mengambil risiko. Adapun penanganan kuratif hanya
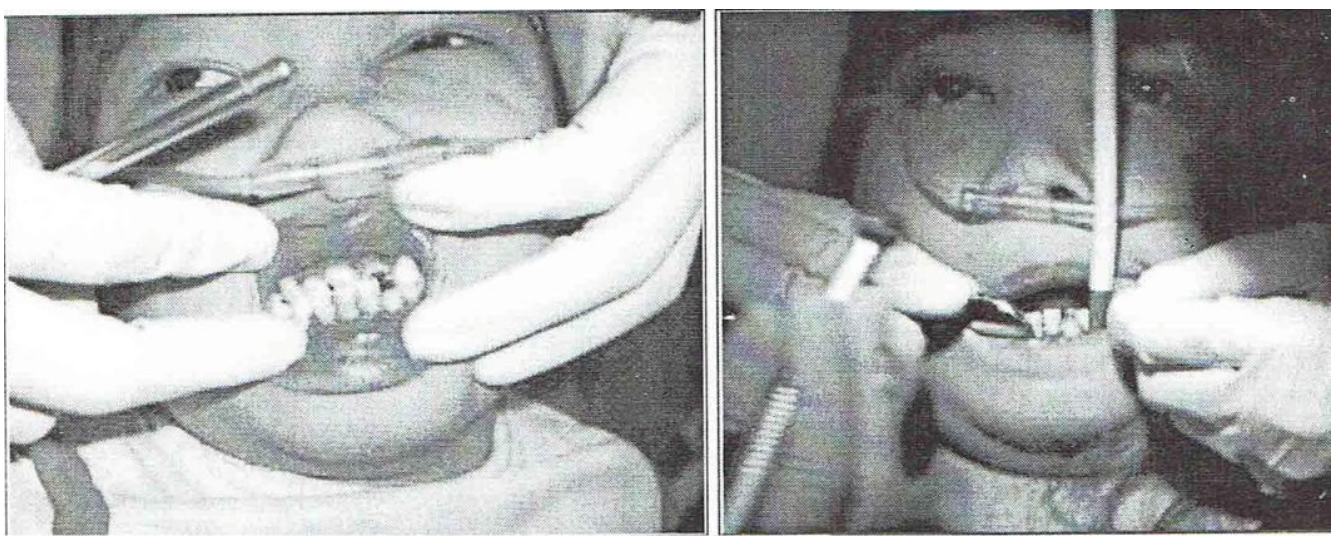

Gambar 3. Gigi anterior yang perlu ditambal (pasien 1)

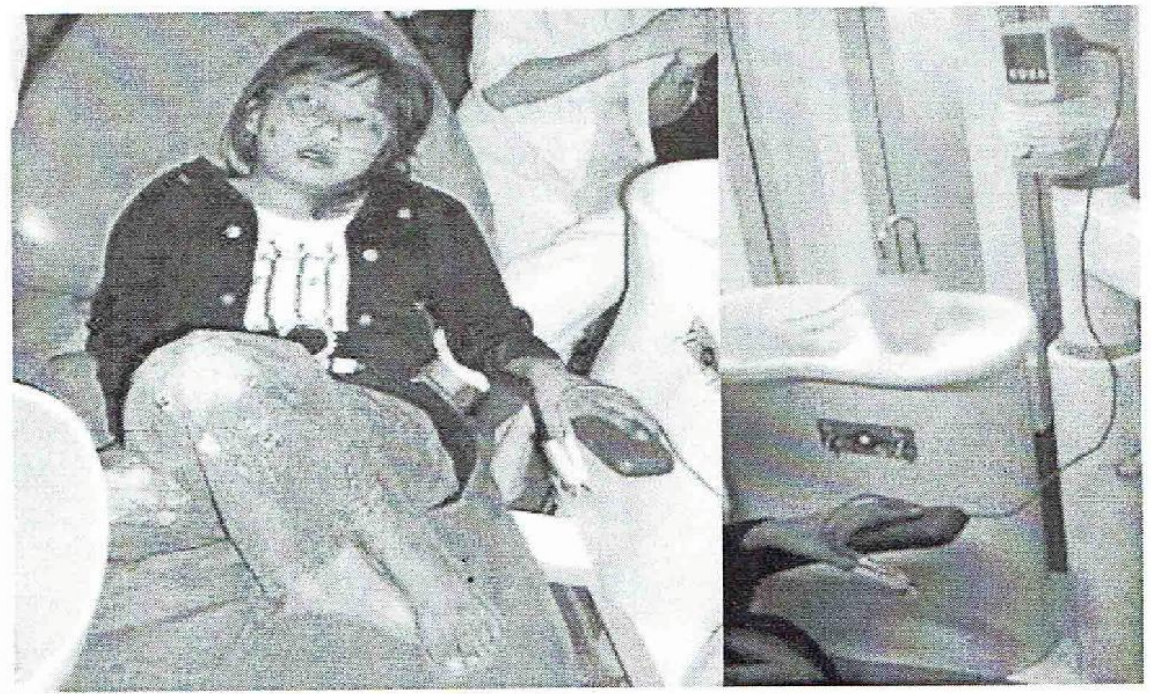

Gambar 4 Monitor dengan pulse oxymetri (panah) selama tindakan 


\section{Kasus Kedua}

Ratna Nurlela, seorang anak berusia 4 tahun juga datang ke klinik Special Dental Care atas rujukan Bagian Kardiolog Anak untuk mencari fokal infeksi dan penatalaksanaannya sebelum dilakukan operasi jantung. Orang tua pasien mengeluhkan adanya gigi yang berlubang, tetapi tidak pernah ada keluhan nyeri gigi dan tidak ada keluhan lain. Diagnosis kerja akhir dari Bagian Kardiologi Anak adalah DF, yaitu compensated Heart Disease; DA, yaitu variant ToF + bakterialis endokarditis; dan DE, yaitu CHD cyanotic type. Dari pemeriksaan fisik tampak pertumbuhan dan perkembangan menunjukkan keterlambatan yang tidak sesuai dengan usia. Pasien tidak kuat berjalan, kulit pucat kebiruan, dan ujung jari-jari kaki dan tangan sianotik, dan clubbing.
Pemeriksaan ekstraoral tidak menunjukkan adanya kelainan. Sedangkan dari hasil pemeriksaan intra oral menunjukkan kebersihan mulut yang buruk dengan adanya karang gigi pada labial regio anterior bawah. Jaringan mukosa bibir, lidah, gingiva, dan mukosa bukal menunjukkan gambaran sianotik. Sedangkan kondisi gigi geliginya menunjukkan adanya karies email dan dentin pada gigi $53,54,55,63,64,65$, 73, 74, 75, 84, 85. Gigi 52,51,62,61 mengalami karies mengenai pulpa dan akar. Selain itu terdapat pula gingivitis marginalis kronis generalisata pada region gigi 71,81 .

Rencana perawatan yang akan dilakukan adalah ekstraksi gigi 52, 51, $61,62,71,81$ dan penambalan gigi 55, $54,53,63,64,65,73,74,75,84,85$.

Profilaksis antibiotik (amoksisilin) diberikan $50 \mathrm{mg} / \mathrm{kg}$ BB 1 jam sebelum tindakan.
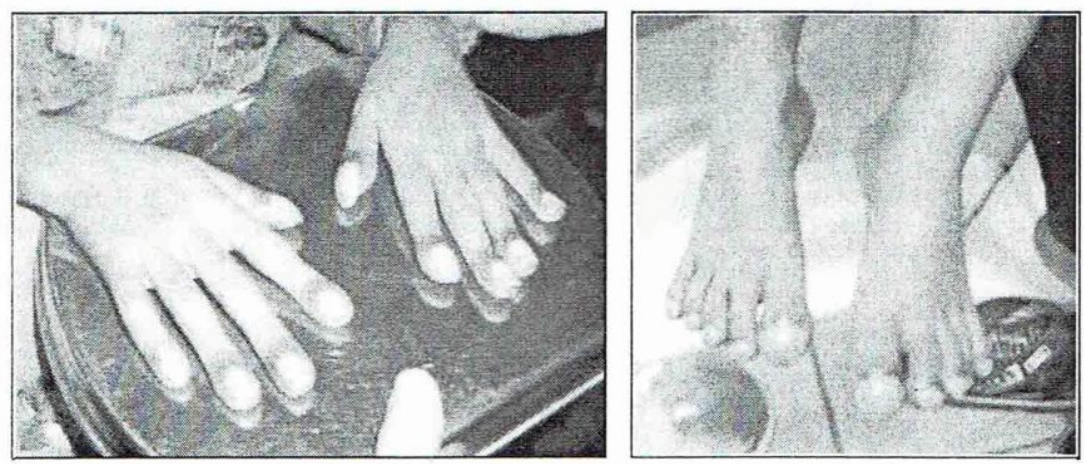

Gambar 5. Ujung jari-jari dan tangan yang sianotik dan clubbing (pasien 2) 


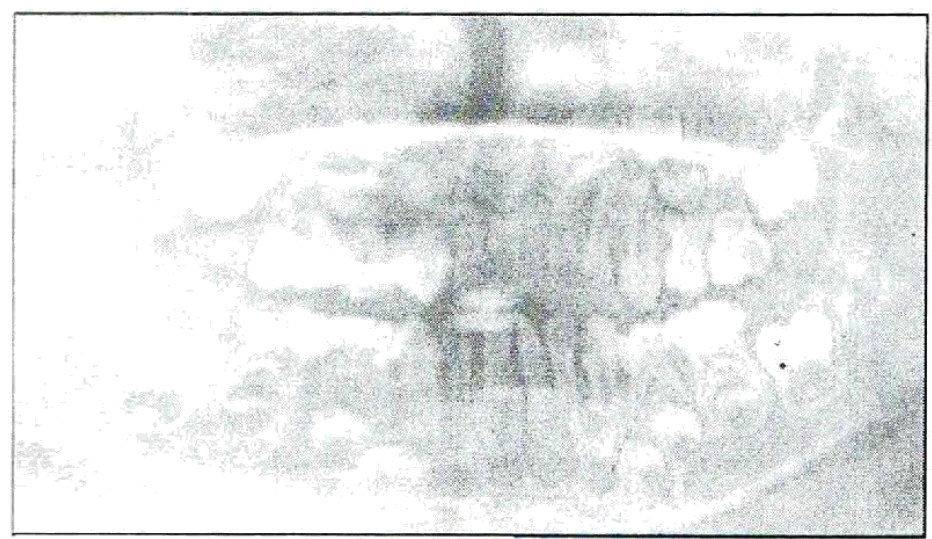

Gambar 6. Gambaran panoramic
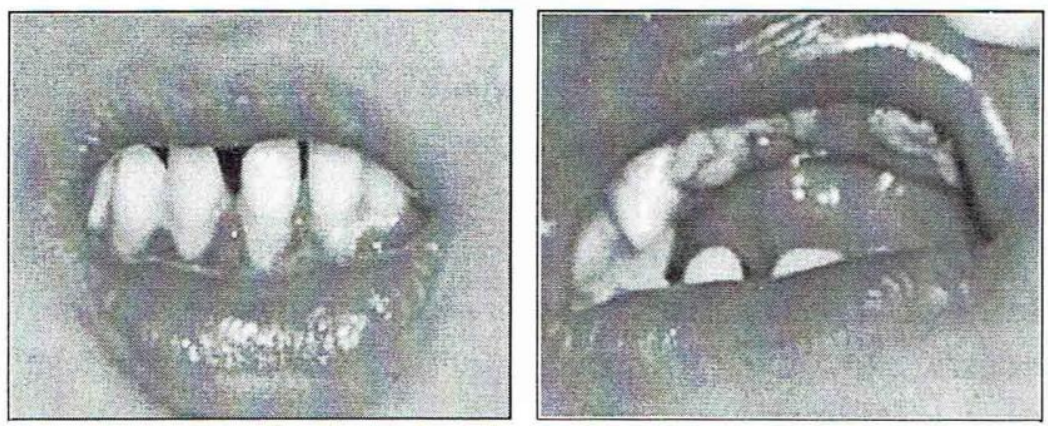

Gambar 8.Tampak gigi anteriori sebelum dilakukan tindakan dengan anastesi umum
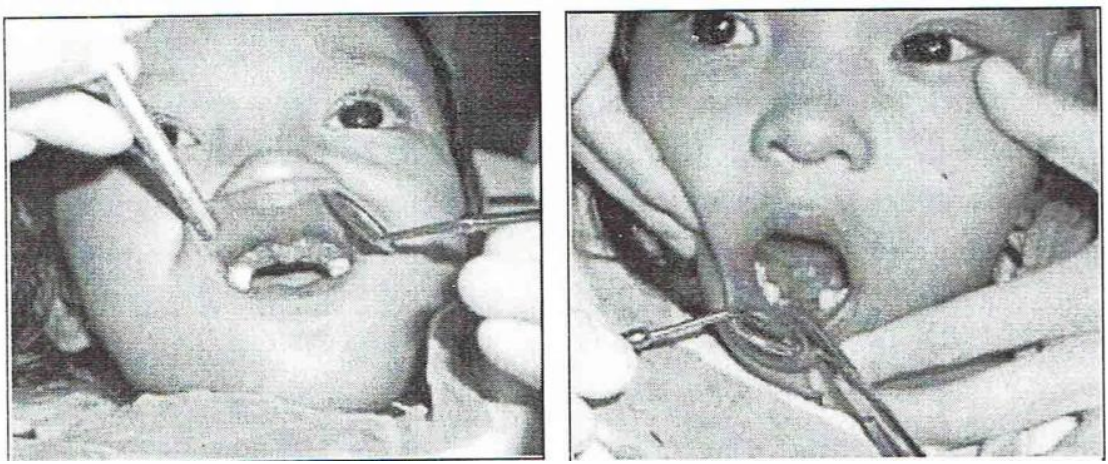

Gambar 9. Pembukaan jahitan setelah ekstraksi dengan anastesi umum (Pasien 2)
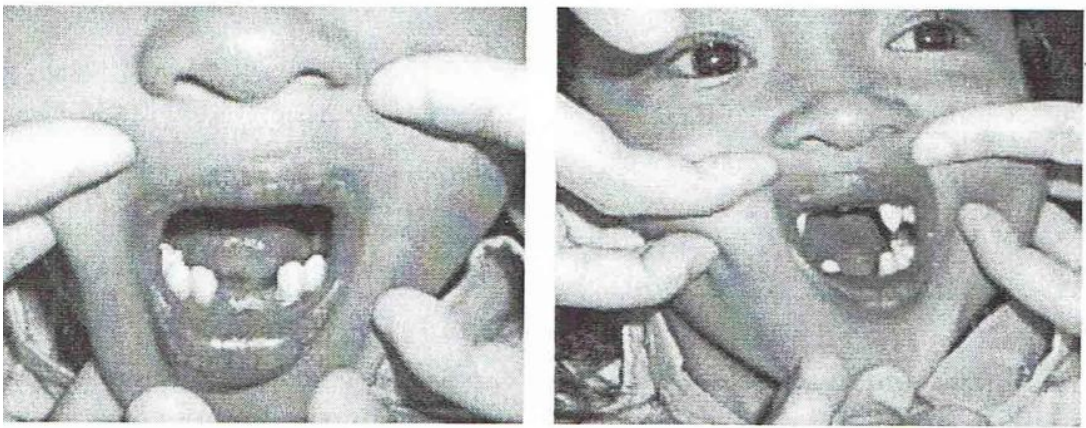

Gambar 10. Setelah penambahan gigi (pasien 2) 
Pada kunjungan pertama dilakukan perawatan dengan pendekatan konvensional (behavior management), namun tidak berhasil karena pasien sangat tidak kooperatif sehingga direncanakan untuk dilakukan perawatan dibawah anestesi umum. Sebelum dilakukan tindakan dibawah anestesi umum, dilakukan pemeriksaan laboratorium, foto ronsen toraks, dan joint conference dengan Bagian Anestesi dan Kesehatan Anak.

Setelah penanganan pasien berupa ekstraksi dengan anastesi umum, pasien dilanjutkan dengan penambalan pada gigi yang didiagnosis dengan hiperemi pulpa. Pasien pada akhirnya dirujuk untuk pelaksanaan operasi jantung di Rumah Sakit Harapan Kita Jakarta DISKUSI.

Perawatan gigi dan mulut pada anak dengan kelainan jantung kongenital, ToF sangat penting dilakukan untuk pencegahan terhadap kemungkinan terdapatnya fokal infeksi. Hal utama yang hams diperhatikan adalah pasien dengan kelainan ini sangat rentan dengan endokarditis bakterialis. Perawatan gigi yang menyebabkan perdarahan pada jaringan lunak dapat menimbulkan bakteremia sementara. Bakteri dalam aliran darah dapat melekat pada defek jantung yang menyebabkan terjadinya endokarditis dan endarteritis bakteri. Pada pasien dengan kelainan jantung dijumpai endokarditis bakteri setelah tindakan scaling tanpa profilaksis dengan antibiotika yang timbul 11-16 hari kemudian. ${ }^{1}$

Untuk mencegah endokarditis diperlukan profilaksis dengan antibiotika pada prosedur dental tertentu. Prosedur dental yang memerlukan profilaksis antibiotika menurut American Heart Association (AHA) adalah ekstraksi gigi, perawatan periodontal meliputi pembedahan, scaling dan root planning, probing, implantasi gigi, anastesi injeksi intra ligament, serta profilaksis oral yang dapat menyebabkan perdarahan. ${ }^{47,11}$

Profilaksis Antibiotika diberikan sebelum dan setelah perawatan gigi, yaitu 1 jam sebelum tindakan dan 6 jam setelah tindakan, kemudian dilanjutkan selama 3 hari berturutturut. Antibiotika yang diberikan secara oral 1 jam sebelum tindakan adalah amoksisilin dengan dosis pada orang dewasa 2,0 gram, dan untuk anak $50 \mathrm{mg} / \mathrm{kg}$ berat badan. ${ }^{8}$

Setiap prosedur perawatan gigi yang dapat menimbulkan kerusakan pada jaringan lunak dapat menimbulkan transient bacteremia 
yang pada keadaan tertentu dapat mengarah pada endocarditis bakterialis. Transient bacteremia dapat terjadi setelah aktivitas fisiologis yang melibatkan mulut, seperti kegiatan mengunyah dan menggosok gigi. Menurut Guntheroth, transient bacteremia yang terjadi setelah kegiatan fisiologis adalah 1000 kali lebih besar dari pada setelah

perawatan gigi. Namun, risiko bakteremia pada pasien dengan keadaan mulut yang bersih dan sehat lebih kecil dibandingkan dengan kebersihan mulut yang buruk. ${ }^{4}$

Endokarditis bakterialis yang disebabkan oleh bakteri oral harus dicegah dengan pemberian profilaksis antibiotik. Antibiotik dapat mencegah endokarditis dengan membunuh bakteri atau merusaknya sehingga dapat dihancurkan oleh pertahanan host. Efek ini dapat terjadi dalam rongga mulut, aliran darah, atau setelah bakteri menempel pada jantung. ${ }^{4}$ Baik pada kasus pertama maupun kedua, profilaksis antibiotik (amoksisilin) diberikan dengan dosis $50 \mathrm{mg} / \mathrm{kg}$ BB 1 jam sebelum tindakan. 7,8

Hal penting yang harus diingat pada pemberian profilaksis antibiotik adalah untuk melakukan perawatan gigi sebanyak mungkin pada setiap kunjugan tetapi harus dengan memperhatikan keadaan emosional pasien. ${ }^{7}$

Selain profilaksis antibiotik, resiko endokarditis dapat dikurangi dengan prosedur perawatan gigi preventif. Hal ini meliputi pemeriksaan gigi rutin, fluoridasi, modifikasi diet untuk mengurangi risiko karies dan penyakit periodontal, dan pemeliharaan kebersihan mulut sehari-hari dengan penyikatan gigi. ${ }^{49}$

Pemberian fluor secara topikal pada kasus pertama ditujukan sebagai perawatan preventif. Sedangkan tindakan kuratif berupa ekstraksi gigigigi dengan diagnosis karies mengenai pulpa dan penambalan gigigigi dengan karies dentin menggunakan semen glass ionomer. Pada pasien normal, gigi-gigi dengan diagnosis karies

mengenai pulpa masih dapat dilakukan perawatan pulpa, namun pada pasien dengan ToF hal ini tidak dapat dilakukan karena risiko endokarditis bakterialis. ${ }^{49}$

Pada pasien pertama tindakan berupa penambalan gigi yang mengalami karies dentin masih dapat dilakukan tanpa anastesi umum dengan pertimbangan pasien masih dalam kriteria kooperatif sehingga perawatan gigi dapat dilakukan 
dengan pendekatan psikologis.

Selama prosedur perawatan gigi, keadaan pasien selalu dimonitor dengan pulse oximetry. Saturasi oksigen pasien di bawah $70 \%$ sehingga pasien diberi oksigen selama tindakan berlangsung. Sedangkan pada tindakan ekstraksi gigi pasien ini hanya dapat dilakukan dibawah anastesi umum, namun dari hasil joint conference, perawatan gigi dibawah anestesi umum tidak dapat dilakukan di RSHS karena pasien termasuk ToF berat sehingga beresiko tinggi pada tindakan operasi dibawah anastesi umum.

Pada kasus kedua, perawatan gigi dan mulut berupa penambalan gigi dengan semen glass ionomer dengan cara konvensional dapat dilakukan dengan disertai pendekatan psikologis yang tepat karena pasien masih kooperatif. Pada pasien direncanakan dilakukan penanganan ekstraksi gigi dibawah anestesi umum, karena jumlah gigi yang akan diekstraksi lebih banyak dan memerlukan waktu tindakan yang lama, disamping itu kondisi pasien penderita ToF ini masih memungkinkan untuk dilakukan perawatan dibawah anastesi umum.

\section{KESIMPULAN}

Seperti halnya kelainan jantung kongenital sianotik lainnya, pada ToF kadang-kadang terjadi komplikasi yang fatal antara lain endokarditis bakterialis. Insidensi endokarditis bakterialis pada Tetralogi Fallot meliputi $15 \%$. Endokarditis bakterialis disebabkan oleh infeksi bakteri pada katup jantung atau endokardium. Di bidang kedokteran gigi, endokarditis bakterialis erat hubungannya dengan infeksi gigi. Perawatan gigi dan mulut sangat penting dilakukan pada pasien dengan risiko endokarditis bakterialis. Pasien dengan keadaan umum yang baik dapat menerima setiap perawatan gigi selama dilindungi dengan profilaksis antibiotik. Aspek penting dari perawatan gigi adalah pendidikan kesehatan gigi, prosedur perawatan gigi preventif, dan pemeliharaan setelah perawatan gigi.

\section{SARAN}

Pendidikan kesehatan gigi dapat mulai diberikan pada saat anak pertama kali menunjukkan kelainan jantung mengingat kelainan jantung kongenital seringkali menunjukkan gejala klinis pada masa bayi. Pendidikan kesehatan gigi yang diberikan sedini mungkin dapat 
mengurangi penyakit gigi dan mulut yang berisiko pada timbulnya endocarditis bakterialis.

\section{DAFTARPUSTAKA}

1. Baraas, F. Penyakit jantung pada anak. Jakarta:

2. Balai Penerbit Fakultas Kedokteran Universitas Indonesia; 1995. p. $140-51$.

3. Dube VK. Dentistry. In: Garson A, Bricker JT,

4. Fisher DJ, Neish SR, Editor. The science and practice of pediatric cardiology, 2nd Ed. Baltimore: Williams \& Wilkins; 1998. p. 290710.

5. Tetralogy of Fallot. Texas: Texas Heart Institute. Available from: www. americanheart. org. 12. McCallum Diakses:28Nopember2005.

6. Markum, AH. Buku ajar ilmu kesehatan anak, jilid 1. Jakarta: Balai Penerbit Fakultas Kedokteran
Universitas Indonesia; 1991. p. 577-81.140-51.

7. Little, JW. Falace DA. Dental management of the medically compromised patient. 6th ed. St. Louis: Mosby Inc.; 2002. p. 21-63.

8. Cameron AC, Widmer RP. Handbook of pediatric dentistry. 2nd ed. Sydney: Mosby Inc.; 2003. p. 234-6.

9. Welburry RR. Paediatric dentistry. 2nd ed. New York: Oxford University Press; 2001. p. 374-8.

10. Gordon IB. Sistem kardiovaskuler. Dalam: Nelson. Ilmu kesehatan anak, Bagian 2.

11. Editor: Behrman RE,Voughan VC. Ali bahasa: Siregar MR. Jakarta: EGC; 1992. p.726-34. CA. Oral surgery for children. In: Clinical pedodontics. 4th ed. Editor: Finn SB. Philadelphia: WB Saunders Co.; 1991. p. 392, 438,581-2. 